\title{
KEANEKARAGAMAN JENIS TUMBUHAN OBAT DAN PEMANFAATANNYA DI KAWASAN TANE' OLEN DESA SETULANG MALINAU, KALIMANTAN TIMUR
}

(Diversity Of Medicinal Plants And It's Utilization At Tane' Olen Setulang Village

Malinau, East Kalimantan)

Oleh/By:

Karmilasanti dan/and Supartini

Balai Besar Penelitian Dipterokarpa, Samarinda

\begin{abstract}
Tane 'Olen is a protected forest in Setulang, South Malinau District, Malinau. This forest is dominated by dipterocarp species and has a high diversity offlora, including plants efficacious as drugs used by the surrounding community. This paper presents the results of research on the utilization of traditional medicinal plants found in the Tane 'Olen is traditionally used by the community of Setulang. The method used in this study is exploratory. Plant material was collected by purposive sampling along the exploration using local people as a species identifier in the region of Tane'Olen.

The results showed that there are 32 species used as traditional medicine, classified in 31 genera and 25 families of plants. Plants species of Family Araceae are most often found. Most of medicinal plants lifeform are trees, while the plant parts used are leaves. Most medicinal plants are used in the form of a single material, consumed directly or indirectly. The traditional medicine mostly use as an external treatment, but sometimes also use for internal treatment.
\end{abstract}

Keywords: Medicinal plants, species diversity, protection forest, Malinau.

\begin{abstract}
ABSTRAK
Tane' Olen adalah kawasan hutan lindung di Desa Setulang, Kecamatan Malinau Selatan, Kabupaten Malinau. Hutan ini didominasi oleh jenis-jenis dipterokarpa dan memiliki keanekaragaman flora yang tinggi, termasuk tumbuhan berkhasiat sebagai obat yang digunakan oleh masyarakat sekitarnya. Tulisan ini memaparkan hasil penelitian mengenai pemanfaatan tumbuhan obat secara tradisional di kawasan Tane' Olen yang secara tradisional digunakan oleh masyarakat Desa Setulang. Metode yang digunakan dalam penelitian ini adalah eksploratif. Materi tumbuhan dikumpulkan secara purposive sampling selama eksplorasi menggunakan pengenal jenis penduduk setempat di kawasan Tane'Olen.

Hasil penelitian menunjukkan bahwa yang digunakan oleh masyarakat setempat sebagai obat tradisional ada 32 jenis, yang tergolong dalam 31 marga dan 26 suku tumbuhan. Araceae merupakan suku tumbuhan yang paling banyak dijumpai. Habitus tumbuhan obat sebagian besar berupa pohon, sedangkan bagian tumbuhan yang paling banyak digunakan adalah daun. Cara
\end{abstract}


penggunaan tumbuhan obat sebagian besar dalam bentuk bahan tunggal, dikonsumsi secara langsung maupun tidak langsung. Penggunaannya sebagian besar untuk pengobatan luar, namun ada juga yang digunakan untuk pengobatan dalam.

\section{Kata kunci : Tumbuhan obat, keragaman jenis, hutan lindung, Tane' Olen.}

\section{PENDAHULUAN}

Kawasan Tane' Olen merupakan kawasan hutan yang dipertahankan oleh masyarakat Desa Setulang sebagai areal yang tetap terjaga dan lestari kondisi hutannya. Hal ini terlihat dari data tingkat kerapatan rata-rata untuk pohon yang berdiameter batang $\geq 20 \mathrm{~cm}$ mencapai 200,71 batang/ha dengan kerapatan pohon tertinggi 234,31 batang/ha dan ini menjadi suatu indikasi bahwa hutan di kawasan tersebut masih dalam kondisi yang baik (Sidiyasa et. al., 2006).

Menurut Sidiyasa et. al., (2006), potensi hutan di kawasan Tane' Olen Desa Setulang dapat dibagi menjadi 4 kelompok berdasarkan jenis pemanfaatannya yaitu pohon penghasil buah-buahan, jenis pohon yang dilindungi, kayu pertukangan dan jenis kayu lainnya. Kelompok kayu pertukangan telah diketahui mendominasi kawasan tersebut, sehingga dapat diprediksi bahwa kawasan Tane' Olen memiliki unsur utama penyusun vegetasi hutan dari jenis-jenis dipterokarpa seperti kelompok meranti merah, meranti putih, tengkawang, keruing, kapur dan meranti kuning.

Selain itu kawasan Tane' Olen juga memiliki keanekaragaman hayati yang melimpah, termasuk tumbuhan hutan yang memiliki khasiat obat. Potensi tumbuhan obat di hutan ini memiliki manfaat yang luar biasa bagi masyarakat lokal di sekitar hutan. Tumbuhan obat ini merupakan tumbuhan yang hidup liar di hutan yang dapat berupa pohon, herba, perdu dan liana. Tumbuhan obat tersebut secara turun temurun dimanfaatkan oleh penduduk asli sebagai obat atau jamu, dengan cara mengambil bagian tumbuhan berupa daun, akar, kulit, batang, getah, bunga, maupun biji dan diproses secara sederhana menjadi ramuan obat untuk menyembuhkan berbagai macam penyakit. Cara pengobatan ini lazim dikenal sebagai pengobatan tradisional (Sari, 2006).

Masyarakat di sekitar kawasan hutan memiliki kearifan lokal dalam pemanfaatan tumbuhan/bahan alami untuk pengobatan. Pengetahuan tentang tumbuhan obat, mulai dari pengenalan jenis tumbuhan, bagian yang digunakan, cara pengolahan sampai dengan khasiat pengobatannya merupakan kekayaan pengetahuan masing-masing etnis dalam masyarakat setempat (Supriadi, 2001). Oleh karena itu, dipandang perlu untuk meneliti pemanfaatan tumbuhan obat secara tradisional oleh masyarakat lokal di Desa Setulang. Tujuan penelitian ini adalah mengetahui keanekaragaman jenis tumbuhan obat yang digunakan oleh masyarakat Desa Setulang. 


\section{METODOLOGI}

\section{A. Lokasi}

Penelitian dilaksanakan di kawasan Tane' Olen Desa Setulang Kecamatan Malinau Selatan Kabupaten Malinau Propinsi Kalimantan Timur.

\section{B. Prosedur Penelitian}

\section{Persiapan}

Kegiatan yang dilakukan pada tahap persiapan penelitian mencakup :

a. Observasi Lapangan

Observasi lapangan adalah kegiatan pengumpulan data dengan cara pengamatan langsung di lapangan dan wawancara dengan informan kunci atau salah satu perangkat desa yang dibutuhkan bantuannya dalam melakukan penelitian, sehingga dapat mendeskripsikan kondisi umum tempat penelitian.

b. Penentuan Informan Kunci

Informan kunci dalam penelitian ini adalah kepala badan pengelola hutan lindung (Tane' Olen) Desa Setulang dan masyarakat yang memiliki keahlian dalam mengenal jenisjenis dan khasiat/manfaat dari tumbuhan obat, walaupun pengetahuannya hanya sampai pada nama lokal.

\section{Metode Pengambilan Sampel}

Sampel tumbuhan obat ditentukan secara purposive sampling berdasarkan eksplorasi, dengan langkah :

a. Eksplorasi/penjelajahan bebas dilakukan pada kawasan Tane' Olen yang menurut informasi masyarakat merupakan habitat tumbuhan obat. Tumbuhan obat diidentifikasi dengan bantuan penduduk setempat sebagai pengenal jenis, tanpa jalur/transek maupun pola tertentu. Eksplorasi/penjelajahan lebih mempertimbangkan kondisi tempat tumbuh/habitat yaitu di sekitar sungai, lembah, lereng dan bukit.

b. Sampel/spesimen tumbuhan obat yang ditemukan di lapangan diambil/dikoleksi terutama dari organ utama tumbuhan seperti daun, bunga, buah dan cabang, untuk diidentifikasi lebih lanjut nama latin/ilmiah (suku, marga dan jenis) tumbuhan obat tersebut. 


\section{Analisis Data}

Data tumbuhan obat yang diperoleh melalui eksplorasi/penjelajahan pada kawasan Tane' Olen dikelompokan dan ditabulasikan, selanjutnya dianalisis secara deskriptif untuk mendapatkan gambaran mengenai pemanfaatan tumbuhan obat secara komprehensif.

\section{HASIL DAN PEMBAHASAN}

\section{A. Keadaan Umum Kawasan Tane’ Olen}

Desa Setulang adalah sebuah desa kecil yang dikelilingi oleh gunung dan hutan tropik, mayoritas dihuni oleh Suku Dayak Kenyah Oma Lung. Keberadaan dan kehidupan Suku Dayak Kenyah Oma Lung di Desa Setulang sangat sederhana dengan mata pencaharian masyarakatnya mayoritas sebagai petani.

Berdasarkan sejarah pengelolaan hutan oleh Suku Dayak Kenyah Oma Lung, terbentuk kesepakatan untuk mempertahankan hutan yang luasnya sekitar 5.300 hektar sebagai hutan lindung (Tane' Olen) yang pengawasan perlindungannya dikuasai atas nama kelompok masyarakat Desa Setulang. Secara geografis, kawasan Tane' Olen terletak antara $3^{\circ} 23^{\prime}-3^{\circ} 29^{\prime}$ Lintang Utara dan antara $116^{\circ} 24^{\prime}-116^{\circ} 29^{\prime}$ Bujur Timur.

Kondisi hutan di kawasan tersebut secara umum sangat baik, walaupun di beberapa tempat terdapat bekas "gangguan", baik oleh alam (angin puyuh) maupun karena ulah manusia. Kerusakan hutan akibat gangguan manusia yang saat ini masih mengancam adalah penyerobotan kawasan oleh perusahaan hutan yang beroperasi di Desa Sentaban (di sebelah utara dan barat laut) dan Desa Setarap (di sebelah selatan dan barat daya). Kerusakan akibat kegiatan perladangan yang pernah terjadi di sepanjang Sungai Setulang sekitar 30 tahun yang lalu, saat ini kondisinya sudah sangat baik.

Hutan primer di kawasan Tane' Olen ini kondisinya cukup baik sehingga masih banyak dijumpai pohon-pohon yang berukuran raksasa dengan tinggi total lebih dari 40 meter dan diameter lebih dari $200 \mathrm{~cm}$. Salah satu pohon besar yang ditemukan memiliki lingkar batang $700 \mathrm{~cm}$ (diameter $223 \mathrm{~cm}$ ) dari jenis Shorea johorensis yang dikenal dengan nama daerah 'Majau', terletak di lereng bukit bagian atas daerah antara anak sungai Tenapan dan Payang (Sidiyasa et al., 2006).

Hasil hutan non kayu berupa tengkawang, rotan, buah-buahan dan obat-obatan juga banyak dijumpai. Peranan dan fungsi lindung kawasan hutan Desa Setulang sudah sangat dirasakan langsung oleh masyarakat desanya, terutama sebagai sumber air bersih, tempat berburu, mengambil rotan, buah-buahan dan yang tidak kalah penting adalah tempat mengambil tumbuhan obat yang telah diketahui khasiatnya oleh masyarakat (Sidiyasa et al., 2006). 


\section{B. Status Pengetahuan Masyarakat Setulang tentang Tumbuhan Obat}

Suku Dayak Kenyah Oma Lung merupakan salah satu sub-etnis asli di Kabupaten Malinau. Etnis ini umumnya tersebar di seluruh wilayah Kabupaten Malinau. Kekayaan adat istiadat dan budaya yang sangat beragam menjadi ciri khas sub-etnis tertentu, terutama dari segi bahasa dan kebiasaan. Seperti halnya masyarakat pedalaman lainnya di Indonesia, masyarakat Setulang juga memilki pengetahuan tentang pengelolaan keanekaragaman sumber daya alam dan lingkungan sekitarnya. Salah satunya adalah pemanfaatan tumbuhan sebagai bahan obat tradisional yang dapat digunakan sehari-hari dan dipercaya untuk menyembuhkan penyakit atau dapat memberikan pengaruh lebih baik terhadap kesehatan.

Masyarakat Setulang umumnya memiliki pengetahuan tentang pemanfaatan tumbuhan obat secara turun temurun di lingkungan keluarga maupun dari pengalamannya sendiri. Sebagian diantaranya bahkan memiliki pengetahuan tentang kegunaan atau khasiat tumbuhan obat dalam kaitnya dengan nilai-nilai religius. Hal inilah yang menyebabkan tidak semua anggota masayarat memiliki pengetahuan tentang tumbuhan obat. Persepsi masyarakat tentang sakit juga sangat bervariasi, mulai dari sakit dalam arti fisik hingga sakit yang disebabkan oleh gangguan makhluk halus/jahat.

Berdasarkan pengamatan, masyarakat Desa Setulang umumnya sudah cukup modern, sehingga hanya ada beberapa orang yang paham dengan jenis-jenis tumbuhan obat dan dapat ditunjuk menjadi tenaga etnobotani. Kondisi ini disebabkan oleh adanya perubahan perilaku, yang semula menggunakan obat tradisional, saat ini cenderung memilih dan menggunakan obat modern dengan alasan praktis (tidak perlu meramu sendiri).

\section{Keanekaragaman Jenis dan Pemanfaatan Tumbuhan Obat}

Tumbuhan di kawasan Tane' Olen yang digunakan oleh masyarakat Desa Setulang sebagai obat tradisional ditemukan sebanyak 32 jenis, tergolong dalam 31 marga dan 25 suku (Tabel 1). Komposisi jenis berdasarkan pengelompokan suku dapat dilihat pada Gambar 1.

Tabel (Table) 1. Jenis dan habitus tumbuhan obat di kawasan Tane' Olen (Species and lifeform of the medicinal plants in Tane'Olen)

\begin{tabular}{|c|l|l|l|l|}
\hline $\begin{array}{c}\text { No. } \\
(\text { No. })\end{array}$ & \multicolumn{1}{|c|}{$\begin{array}{c}\text { Nama daerah } \\
(\text { Local name })\end{array}$} & $\begin{array}{c}\text { Jenis Tumbuhan Obat } \\
(\text { Medicinal plants species })\end{array}$ & $\begin{array}{c}\text { Suku } \\
(\text { Family })\end{array}$ & $\begin{array}{c}\text { Habitus } \\
(\text { Lifeform })\end{array}$ \\
\hline 1. & Kele he'la & Homalanthus populneus & Euphorbiaceae & Pohon \\
\hline 2. & Adau & Elmerrillia tsiampacca & Magnoliaceae & Pohon \\
\hline 3. & Bele'em & Eusideroxylon zwageri & Lauraceae & Pohon \\
\hline 4. & Daeng kelingo hazau & Octomeles sumatrana & Datiscaceae & Pohon \\
\hline 5. & A'ga omang & Flacourtia rukam & Flacourtiaceae & Pohon \\
\hline
\end{tabular}




\begin{tabular}{|c|l|l|l|l|}
\hline 6. & Loweny & Baccaurea lanceolata & Phyllanthaceae & Pohon \\
\hline 7. & Page lemek & Planchonia sp. & Lecythidaceae & Pohon \\
\hline 8. & Akar kedayan & Litsea garciae & Lauraceae & Pohon \\
\hline 9. & Benebang & $\begin{array}{l}\text { Goniothalamus } \\
\text { macrophyllus }\end{array}$ & Annonaceae & Pohon \\
\hline 10. & Daeng Bago & Casearia sp. & Salicaceae & Pohon \\
\hline 11. & Kelaruk/sirih & Hoya sp. & Apocynaceae & Liana \\
\hline 12. & Save bali & Aristolochia sp. & Aristolochiaceae & Liana \\
\hline 13. & Opa & Schindapsus sp. & Araceae & Liana \\
\hline 14. & Fhoang & Piper sp. & Piperaceae & Liana \\
\hline 15. & Daeng to'beng & Bauhinia dipteral & Leguminosae & Liana \\
\hline 16. & U'de pa'deng & Gmelina sp. & Verbenace ae & Liana \\
\hline 17. & Tatto & Pycnarrhena tumefacta & Menispermaceae & Liana \\
\hline 18. & Lefesu & Alocasia scabriculata & Araceae & Herba \\
\hline 19. & Libeng bayi & Costus speciosus & Costaceae & Herba \\
\hline 20. & Ta'ben & Alocasia sp. & Araceae & Herba \\
\hline 21. & Radupu & Paspalum conjugatum & Poaceae & Herba \\
\hline 22. & Pohon Mali & Homalomena sp. & Araceae & Herba \\
\hline 23. & Akha kerek & Leea indica & Leeaceae & Perdu \\
\hline 24. & Beke & Senna alata & Leguminosae & Perdu \\
\hline 25. & Boo & Blumea balsamifera & Asteraceae & Perdu \\
\hline 26. & Daeng pung & Callicarpa longifolia & Verbenaceae & Perdu \\
\hline 27. & Ucung ace & Solanum torvum & Solanaceae & Perdu \\
\hline 28. & Bowem & Diplazium esculentum & Athyriaceae & Paku \\
\hline 29. & We bala/rutan merah & Asplenium cf. phyllitidis & Aspleniaceae & Paku \\
\hline 30. & Lung & Tectaria sp. & Polypodiaceae & Paku \\
\hline 31. & Penek lana & Korthalsia furtadoana & Arecaceae & Palma \\
\hline 32. & Ulem & Medinilla alternifolia & Melastomataceae & Epifit \\
\hline
\end{tabular}




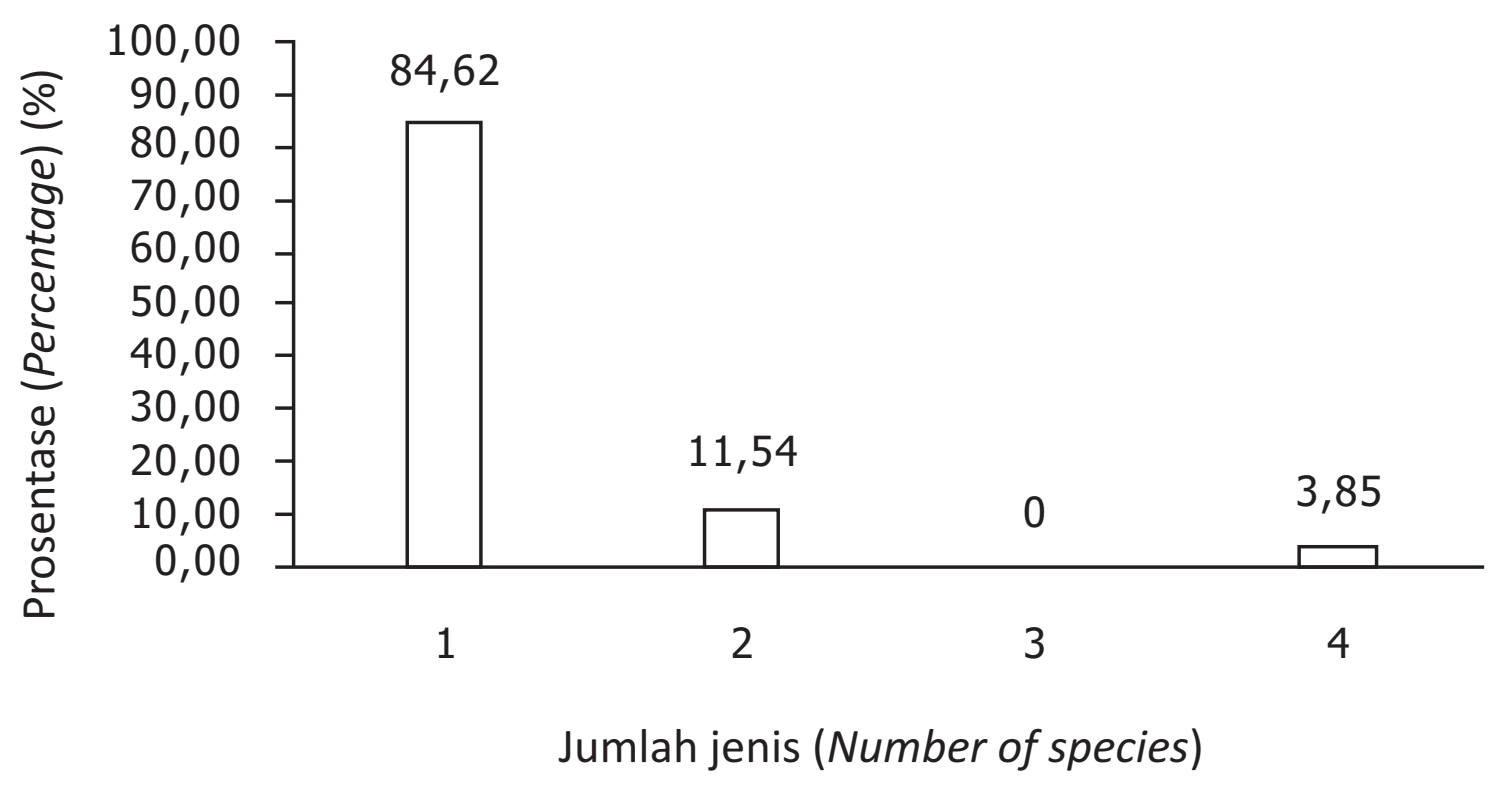

Gambar(Figure) 1. Kelompok suku yang memiliki jumlah jenis yang sama (Group offamily having the same number of species )

Berdasarkan jumlah jenis yang dimiliki oleh setiap suku, data terkelompok menjadi tiga yaitu kelompok pertama terdiri dari suku-suku yang memiliki 1 jenis sebesar 84,62\% meliputi Magnoliaceae, Athyriaceae, Arsitolochiaceae, Datiscaceae, Piperaceae, Leeaceae, Aspleniaceae, Poaceae, Lecythidaceae, Melastomataceae, Menispermaceae, Annonaceae, Asteracae, Arecaceae, Flacourtiaceae, Apocynaceae, Costaceae, Euphorbiaceae, Phyllantaceae, Polypodiaceae, Salicaceae dan Solanaceae; kelompok kedua terdiri dari suku Lauraceae, Leguminosae/Fabaceae dan Verbenaceae dengan masing-masing 2 jenis dan kelompok ketiga adalah suku yang memiliki 4 jenis yaitu Araceae.

Berdasarkan data pada Tabel 1 juga dapat diketahui habitus masing-masing jenis tumbuhan obat yang digunakan oleh masyarakat Desa Setulang. Menurut habitusnya, ke-32 tumbuhan obat tersebut dapat dikelompokkan seperti pada Gambar 2 berikut ini. 


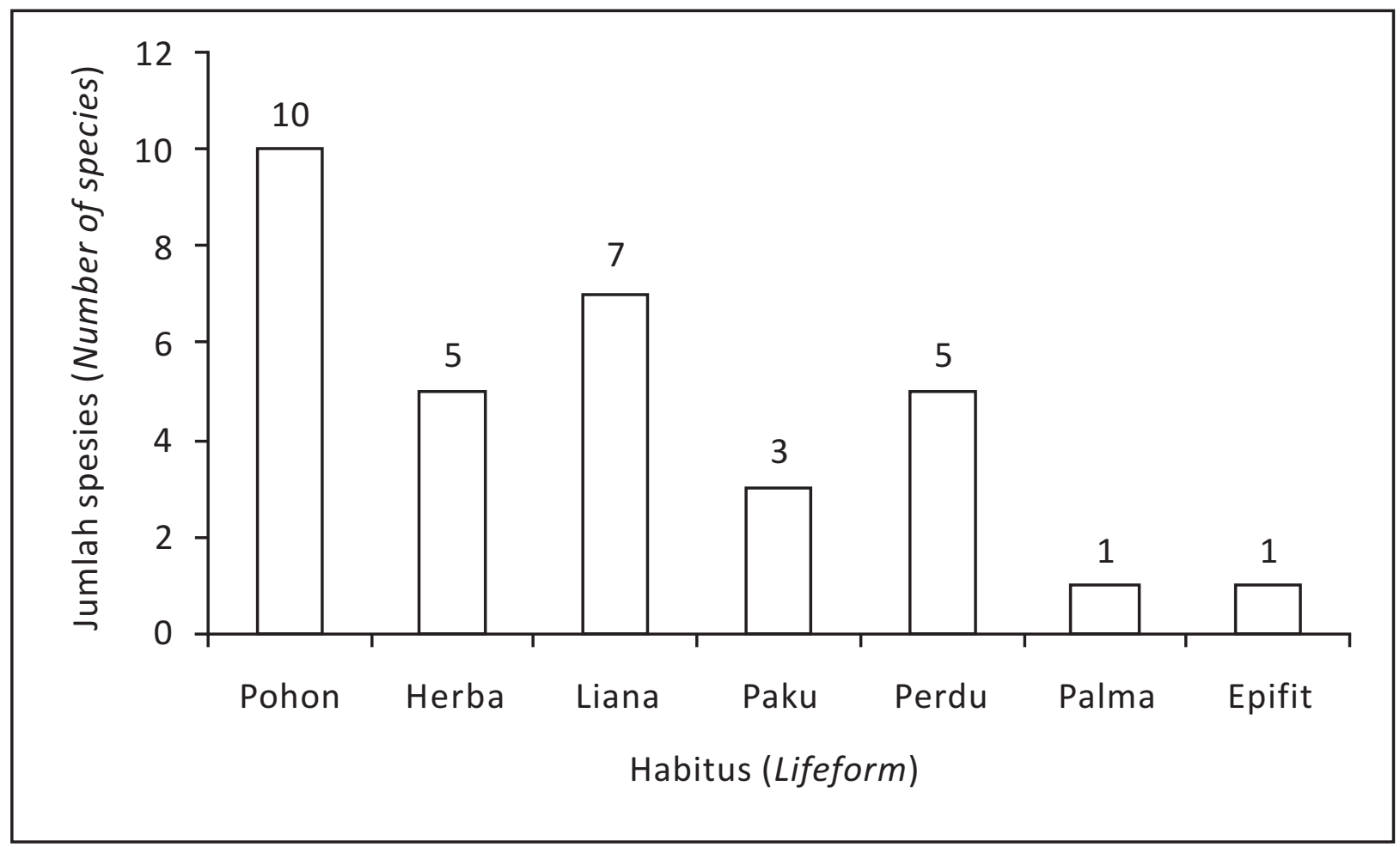

Gambar (Figure ) 2. Jumlah jenis tumbuhan obat berdasarkan habitus (Number of medicinal plant species based on lifeform).

Habitus tumbuhan obat yang terdapat di hutan tersebut sebagian besar berupa pohon (10 jenis). Berdasarkan pengamatan di lapangan, kawasan Tane' Olen termasuk kedalam struktur hutan hujan tropis primer, sehingga jumlah individu terbanyak dijumpai pada kelompok pohon. Hal ini sesuai dengan hasil penelitian (Sidiyasa K., et al, 2006) yang menyatakan bahwa ukuran penyusun komunitas hutan Tane' Olen sangat bervariasi, ukuran lingkar batang terkecil dan terbesar mencapai $31,4 \mathrm{~cm}$ dan 1,250 cm, rentang ukuran tersebut tergolong besar. Menurut penelitian ini, jumlah individu terbanyak dijumpai pada kelompok pohon dengan ukuran diameter batang kecil yaitu 10 $29 \mathrm{~cm}$. Jenis pohon tersebut adalah : Omalanthus populneus, Elmerrillia tsiampacca, Eusideroxylon zwageri, Octomeles sumatrana, Flacourtia rukam, Baccaurea lanceolata, Planchonia sp., Litsea garciae, Goniothalamus macrophyllus, dan Casearia sp. Tumbuhan dengan habitus pohon tersebut banyak dijumpai di daerah lereng dan bukit.

Tumbuhan obat berhabitus lainnya antara lain : liana ( 7 jenis), herba dan perdu (masingmasing 5 jenis), paku (3 jenis), palma dan epifit (masing-masing 1 jenis). Salah satu penyebab tumbuhan berhabitus selain pohon tersebut jumlahnya sedikit karena kondisi kawasan Tane' Olen yang didominasi pohon sehingga penutupan tajuknya sangat rapat dan belum pernah terjadi eksploitasi sehingga vegetasi di lapisan bawah (lantai hutan) secara umum memiliki persentase 
tumbuh yang agak kurang. Berdasarkan data yang diperoleh di lapangan, tumbuhan obat berhabitus bukan pohon (liana, herba, perdu, paku, palma dan epifit) banyak dijumpai di pinggir sungai atau daerah-daerah yang agak terbuka (gap) yaitu daerah dimana sinar matahari dapat menembus lantai hutan.

Berdasarkan informasi masyarakat Setulang semua jenis tumbuhan obat yang diperoleh di lapangan bukan merupakan jenis asli (endemik) atau hanya ditemukan di daerah tersebut. Jenisjenis tersebut hampir juga dapat ditemukan tersebar di seluruh wilayah Kabupaten Malinau.

Jenis, kegunaan, bagian tumbuhan dan cara penggunaan tumbuhan obat yang dimanfaatkan oleh masyarakat Desa Setulang disajikan pada Tabel 2. Bagian tumbuhan yang paling banyak digunakan untuk pengobatan oleh masyarakat adalah daun. Bagian tumbuhan lain yang juga digunakan adalah batang, kulit, akar, getah dan umbi. Hasil wawancara menunjukkan bahwa cara penggunaan tumbuhan obat tersebut sebagian besar dalam bentuk tunggal yaitu tumbuhan diramu tanpa dicampur dengan bahan lain.

Masyarakat Desa Setulang umumnya menggunakan tumbuhan obat dengan cara dikonsumsi secara langsung maupun tidak langsung (dengan perlakuan tertentu sebelum digunakan). Getah dan kulit tumbuhan obat tertentu umumnya digunakan secara langsung dengan dioleskan pada luka, serta daunnya ditempel pada bagian yang sakit. Penggunaan tidak langsung dilakukan dengan cara ditumbuk, diremas, dihancurkan, dipotong-potong, direbus atau dimasak, dibakar dan diminum. Penggunaan tumbuhan obat sebagian besar untuk pengobatan luar, meskipun ada juga penggunaan untuk pengobatan dalam. 


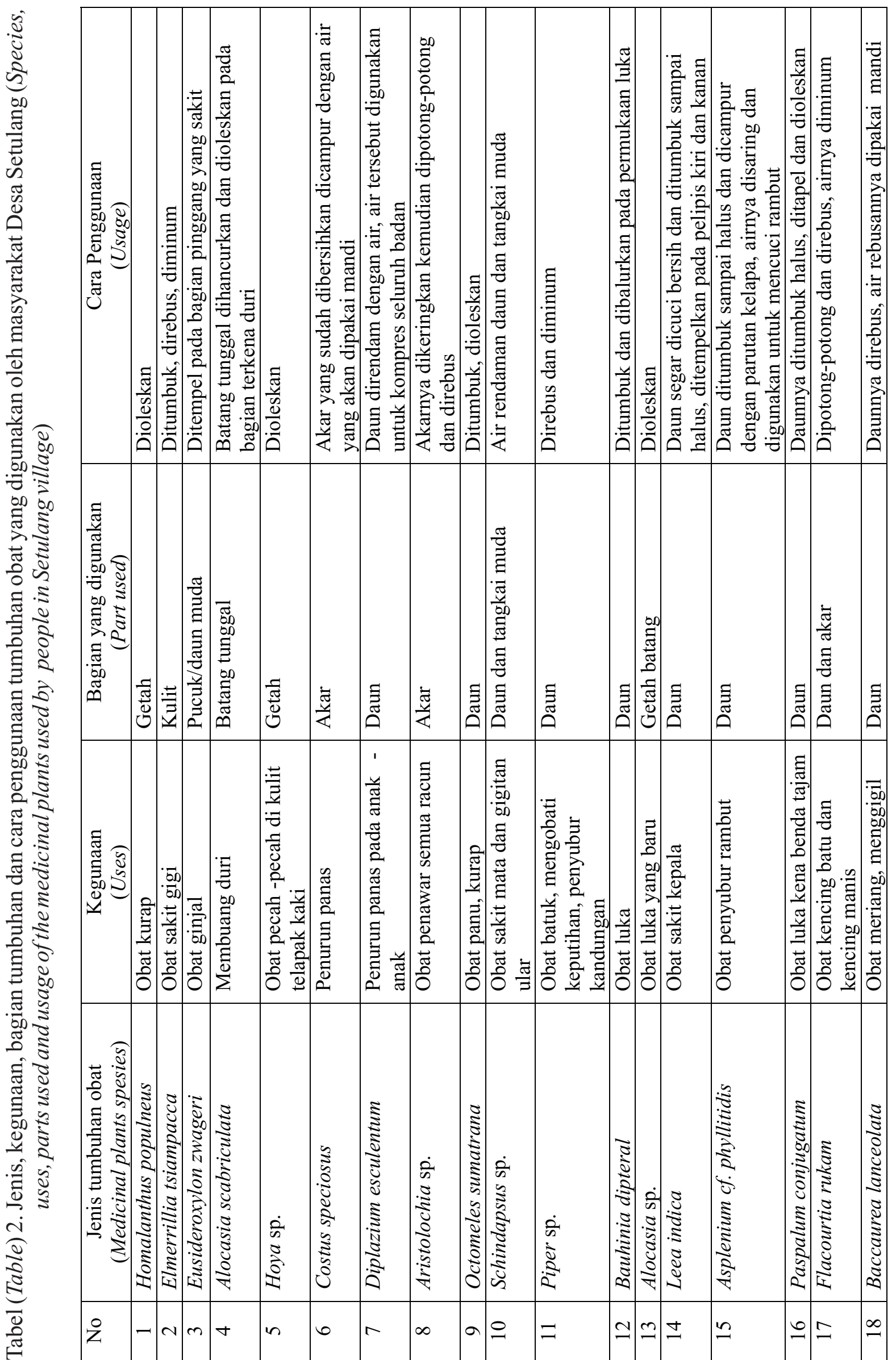




\begin{tabular}{|c|c|c|c|c|c|c|c|c|c|c|c|c|}
\hline 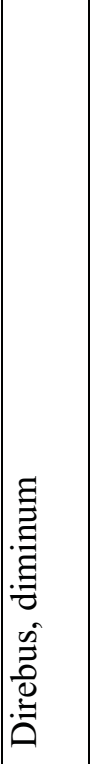 & 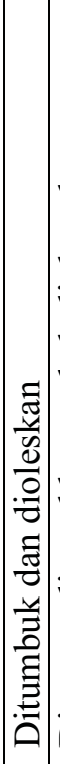 & 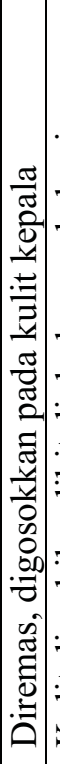 & 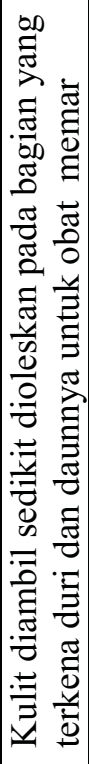 & 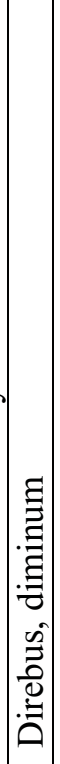 & 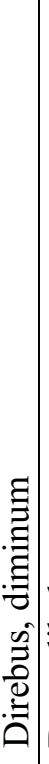 & 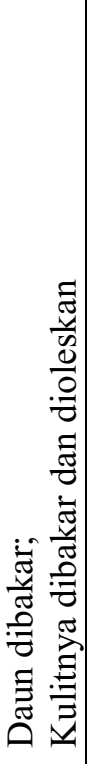 & 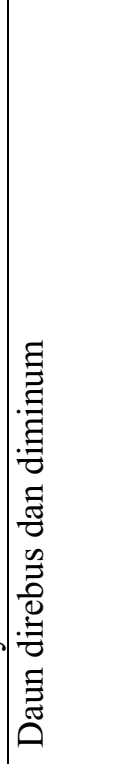 & 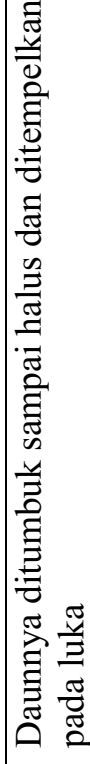 & 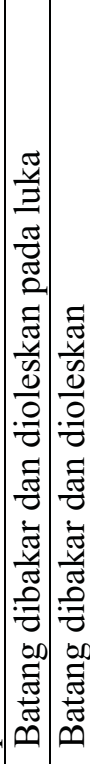 & 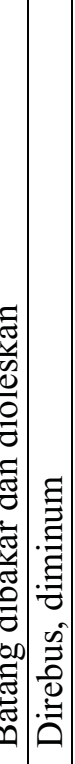 & 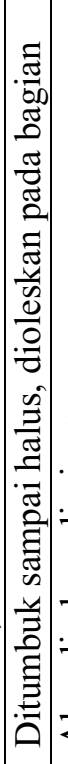 & 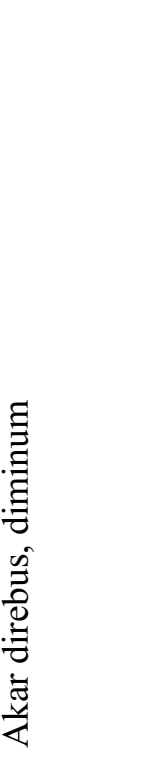 \\
\hline 帚 & 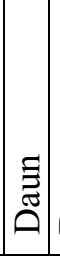 & 焉: & 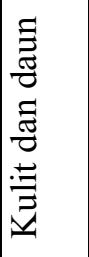 & 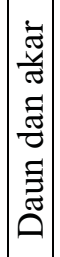 & : & 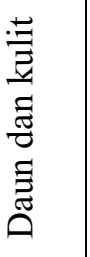 & 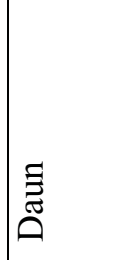 & 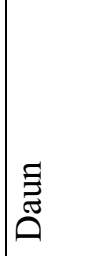 & 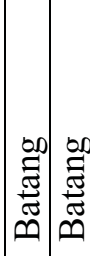 & 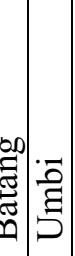 & 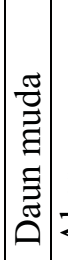 & $\frac{\bar{z}}{\vec{z}}$ \\
\hline 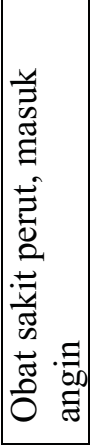 & 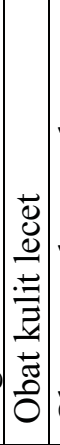 & 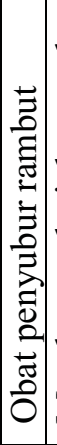 & 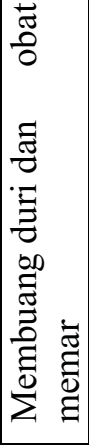 & \begin{tabular}{|l} 
\\
0 \\
0 \\
$: \frac{\pi}{3}$ \\
$\frac{\pi}{\pi}$ \\
0 \\
0 \\
0
\end{tabular} & 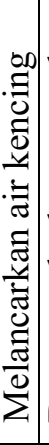 & 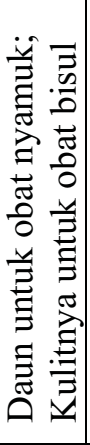 & 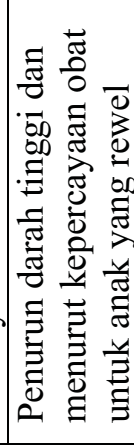 & 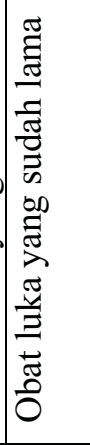 & 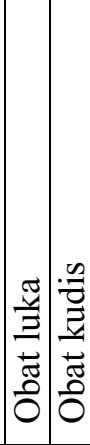 & 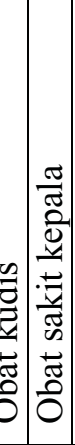 & 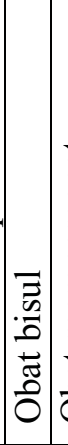 & 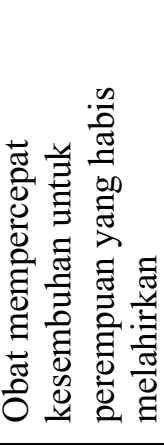 \\
\hline 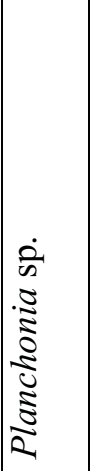 & $\left|\begin{array}{c}0 \\
0 \\
0 \\
0 \\
\vdots \\
\vdots \\
5 \\
2\end{array}\right|$ & 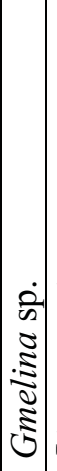 & 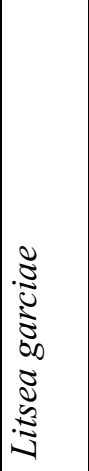 & 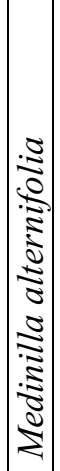 & 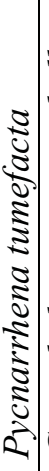 & 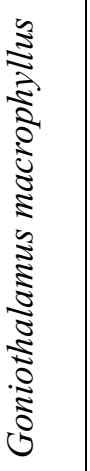 & 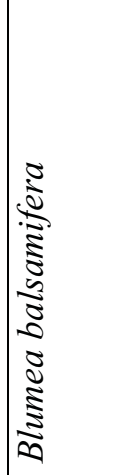 & 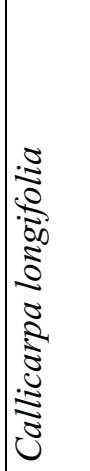 & 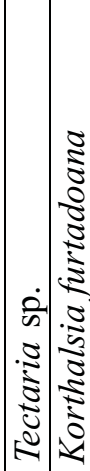 & 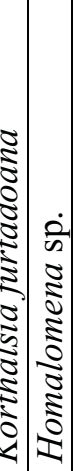 & 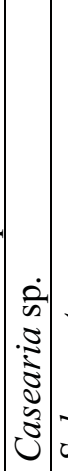 & 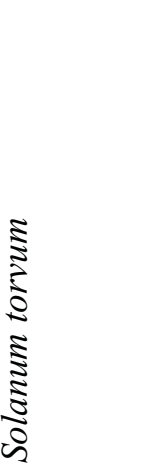 \\
\hline 2 & ิ) & $\bar{\nu}$ & $\tilde{\lambda}$ & $\approx$ & $\sim$ & 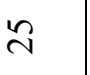 & సి & $\hat{\sim}$ & 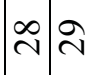 & જે & $\bar{n}$ & ले \\
\hline
\end{tabular}




\section{KESIMPULAN}

1. Tumbuhan obat di kawasan Tane' Olen yang digunakan oleh masyarakat Desa Setulang ditemukan sebanyak 32 jenis, tergolong dalam 31 marga dan 26 suku dengan habitus sebagian besar berupa pohon dan bagian tumbuhan yang banyak dimanfaatkan adalah daun.

2. Kegunaan tumbuhan obat dengan habitus pohon antara lain : sebagai obat kurap, sakit gigi, ginjal, panu/kurap, kencing batu dan kencing manis, meriang/menggigil, sakit perut/masuk angin, obat memar, obat nyamuk dan bisul.

3. Kegunaan tumbuhan obat dengan habitus liana antara lain : obat pecah-pecah untuk kulit kaki, penawar racun, sakit mata dan gigitan ular, batuk/keputihan/penyubur kandungan, obat luka, penyubur rambut dan melancarkan air kencing.

4. Kegunaan tumbuhan obat dengan habitus herba antara lain : membuang duri, penurun panas, obat luka yang baru, obat luka kena benda tajam dan obat sakit kepala.

5. Kegunaan tumbuhan obat dengan habitus perdu antara lain : obat sakit kepala, kulit lecet, penurun darah tinggi, mengatasi rewel pada anak (kepercayaan setempat), obat luka lama dan mempercepat kesembuhan untuk wanita yang habis melahirkan.

6. Kegunaan tumbuhan obat dengan habitus paku antara lain : penurun panas pada anak-anak, penyubur rambut dan obat luka; sedangkan tumbuhan berhabitus palma dan epifit berfungsi sebagai obat kudis dan diare.

7. Umumnya tumbuhan obat digunakan dalam bentuk bahan tunggal, dikonsumsi secara langsung untuk pengobatan luar. 


\section{DAFTAR PUSTAKA}

Kristin, D. 2007. Inventarisasi Tumbuhan Berkhasiat Obat di Hutan Mitra Alam, Kecamatan Malinau Barat Kabupaten Malinau. Skripsi Fakultas Kehutanan Universitas Mulawarman. Samarinda.

Sari, N. 2006. Survey Tumbuhan Obat di Kawasan Wisata Alam Sangkima Taman Nasional Kutai Kalimantan Timur. Balai Taman Nasional Kutai Kalimantan Timur. Bontang.

Sidiyasa, K., Zakaria, Iwan, R. 2006. Hutan Desa Setulang dan Sengayan Malinau, Kalimantan Timur : Potensi dan Identifikasi Langkah-langkah Perlindungan dalam Rangka Pengelolaannya Secara Lestari. Center for International Forestry Research (CIFOR). Inti Prima Karya Indonesia. Bogor.

Supriadi, 2001. Tumbuhan Obat Indonesia Penggunaan dan Khasiatnya. Yayasan Obor Indonesia. Jakarta.

Wijayakusuma, H., Dalimartha, S., Wirian, A.S., Yaputra, T., dan Wibowo, B. 1992. Tanaman Berkhasiat Obat di Indonesia Jilid 2. Pustaka Kartini. Jakarta.

Wijayakusuma, H. 2002. Tumbuhan Berkhasiat Obat Indonesia, Rempah, Rimpang dan Umbi, Manfaat dan Penggunaannya. Millenia Populer. Jakarta.

Zuhud, E. A. M., 1997. Mencari Nilai Tambah Potensi Hasil Hutan Non Kayu. Tumbuhan Obat Berbasiskan Pemberdayaan Masyarakat Tradisional Sekitar Hutan. Makalah Seminar Mencari Nilai Tambah Potensi Hasil Hutan Untuk Tanaman Obat. Institut Pertanian Bogor. Bogor. 
Lampiran(Appendix) 1. Photo-photo tumbuhan obat di Kawasan Tane' Olen (photos of the medicinal plants in Tane' Olen).

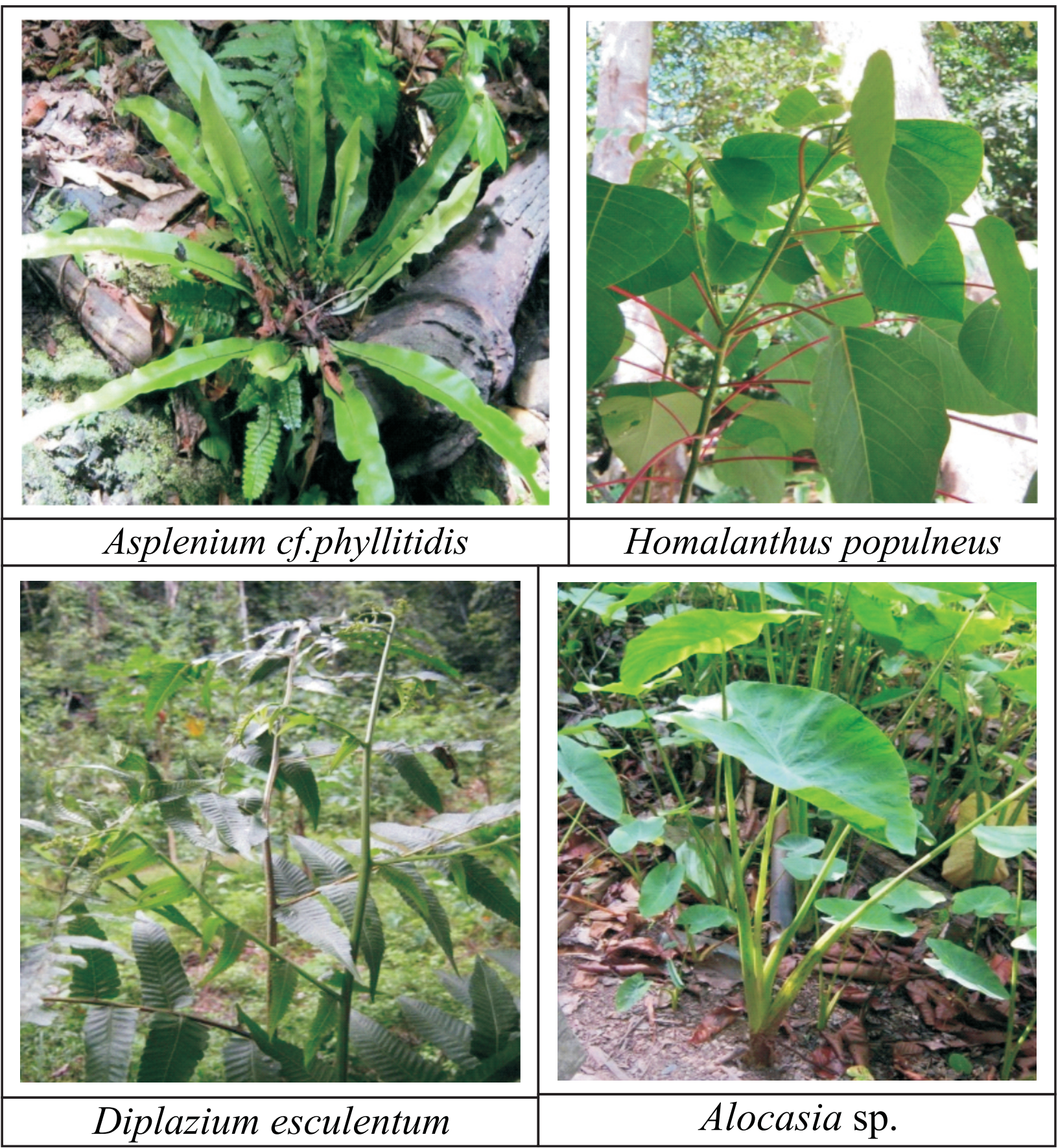




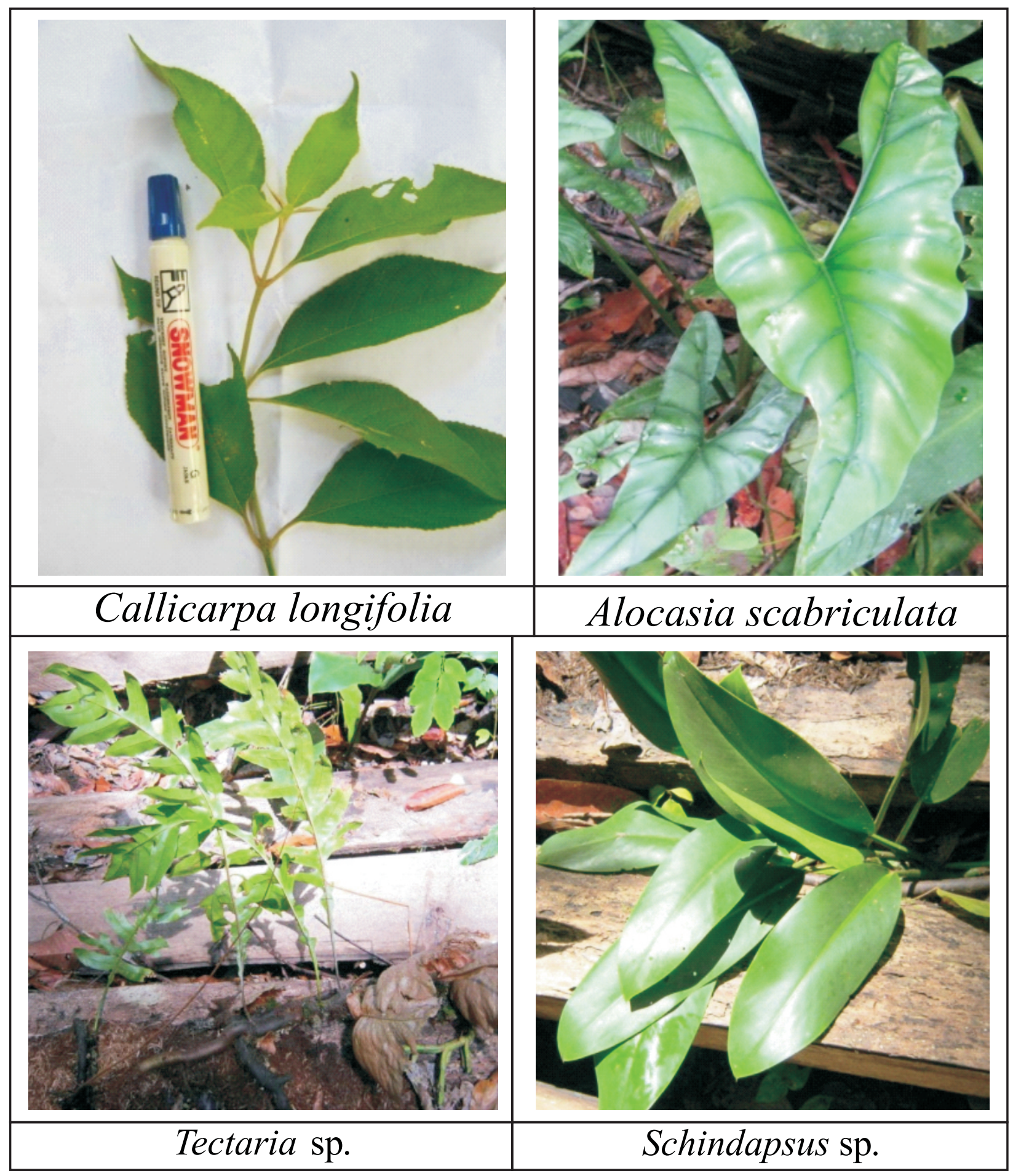




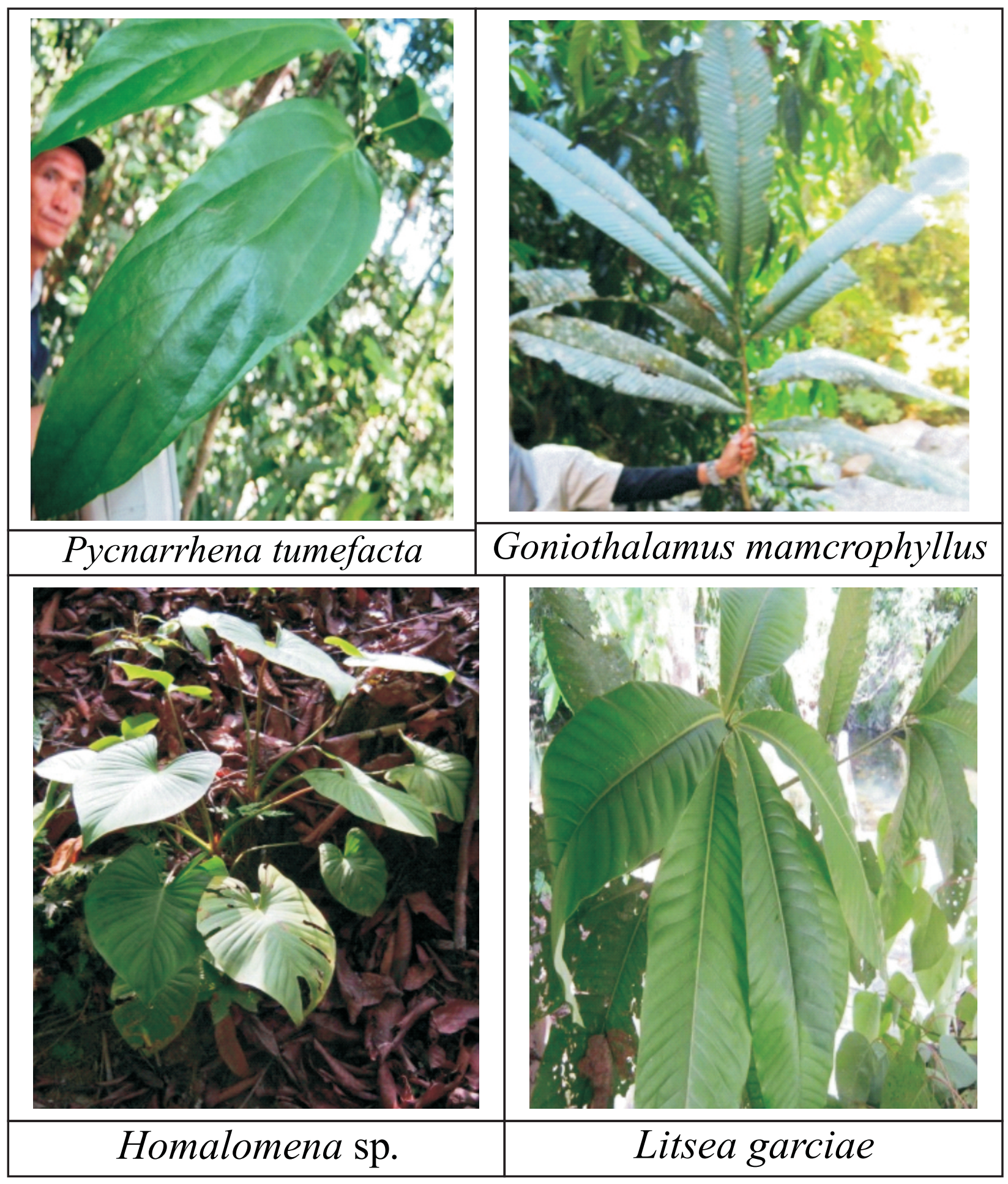

